Sisay Demissew Beyene - Balázs Kotosz

\title{
Testing the Ricardian equivalence hypothesis in the case of Ethiopia: An autoregressive-distributed lag approach
}

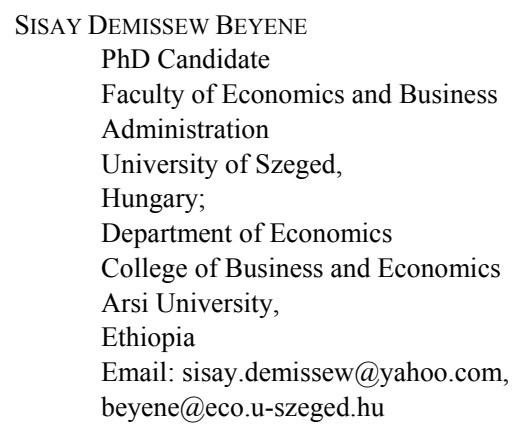

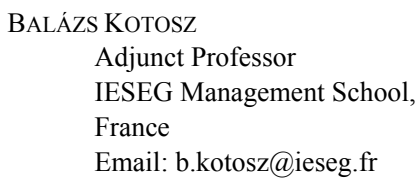

The Ricardian equivalence hypothesis (REH) suggests that when the government attempts to stimulate the economy by raising debt-financed government spending, consumption and demand do not increase but rather remain the same. The objective of this study is to test the existence of the REH in Ethiopia, using annual data from 1990 to 2011 and by employing the autoregressivedistributed lag cointegration approach. The study includes three variables (budget deficit, government consumption expenditure, and government debt) which contribute to the REH along with another variable. The results show that only the budget deficit and government consumption expenditure fulfil the REH. However, government debt fails to fulfil it. Thus, limited evidence of the existence of the REH is found in Ethiopia.

KEYWORDS: Ricardian equivalence hypothesis, autoregressive-distributed lag cointegration, Ethiopia

The Ricardian equivalence theorem, formulated by the British classical economist David Ricardo, was immediately dismissed as being irrelevant. However, neoclassical economist, Robert Barro forcefully argued that the REH is worthy of professional attention and yields important policy prescriptions (Heijdra [2002]).

HungaRian STATISTICAL REVIEW, VOLUME 3, NUMBER 2, PP. 26-49. DOI: 10.35618/hsr2020.02.en026 
There are two main dimensions of dealing with the REH: the first, Keynesian proposition and second, the Ricardian equivalence hypothesis itself. According to Okpanachi-Abimiku [2007] cited in Dalyop [2010], Keynesians argue that increasing government spending by running a budget deficit enhances domestic output, which stimulates the economy in the short run by making households feel wealthier, thus, raising total private and public consumption expenditure. Further, according to the Keynesian argument, consumers treat government debt as net wealth. Therefore, substitution of debt for taxes has a positive impact on private consumption and aggregate demand, even though it increases the real interest rate and leads to the crowding out of private investment and slowing of the economy (Marinheiro [2001]). However, in a sticky-price model within a large economy, a fiscal expansion increases the real interest rate. This increase, in turn, leads to a fall in private consumption (Kim-Roubini [2008]).

Nevertheless, the Ricardians argue that since a tax cut now is a tax increase in the future, the substitution of debt for taxes has no effect on aggregate demand or on the interest rate. Further, anticipated consumers assume that today's borrowings are postponed taxes of the future, meaning that the consumers' level of consumption remains unchanged due to their savings today. Furthermore, under the REH, consumers respond to a reduction in tax by increasing their savings by buying securities, which helps to pay the increased future taxes and repay future debt. Thus, when private savings increase by the same amount as the budget deficit, both the national savings as well as the interest rate will be unchanged. Hence, for a given expenditure path, financing the public expenditure either by debt or by taxation does not affect private consumption (Marinheiro [2001]). In addition to taxation, issuing bonds is one way to finance government expenditure. Since these bonds are considered as loans, they will be paid back by increasing tax revenues. This is the choice between 'tax now or later'. If the government chooses the 'tax later' principle to finance its deficit, according to the REH, the taxpayers expect higher taxes in the future. Hence, fearing future taxes, economic agents will increase their savings by reducing their current level of consumption. Similarly, if the government had chosen the 'tax now' principle, there would be a similar effect on aggregate demand.

Additionally, there is contradictory empirical evidence on the existence of the REH in different parts of the world. For example, certain studies support the REH (Tanner [1979]; Kormendi [1983]; Evans [1988], [1993]; LeidermanRazin [1988]; Kormendi-Meguire [1990]; Issler-Lima [2000]; GiorgioniHolden [2003]; Olasunkanmi-Akanni [2013]; Mosikari-Eita [2017]). In contrast, other studies (Yawitz-Meyer [1976], Buiter-Tobin [1979], ModiglianiSterling [1986], Bernheim [1987], Kazmi [1994], Graham-Himarios [1996], Drakos [2001], Marinheiro [2001], Onafowora-Owoye [2006], VamvoukasGargalas [2008], Fang-Ma-Sheng [2010], Waqas-Awan [2011], Saeed-Khan [2012],

Hungarian Statistical ReVIEW, VOLUME 3, NumBER 2, PP. 26-49. DOI: 10.35618/hsr2020.02.en026 
Onyeiwu [2012], Odianye-Ebi [2013], Aderemi [2014]) have not found any supporting evidence. Furthermore, some studies have found inconclusive results (Gupta [1992], Kaadu-Uuskula [2004]). Moreover, the issues surrounding the effect of fiscal policies (the variables in the REH) are on today's global agenda; however, in the case of Ethiopia, there is lack of country-relevant empirical studies (even Pickson-Ofori-Abebrese [2018] did not include Ethiopia in the testing of the REH for Sub-Saharan African countries). This has resulted in a knowledge gap in the literature, necessitating a systematic examination.

Owing to the above contradicting theories, inconclusive empirical findings, and lack of country-relevant empirical studies in the context of Ethiopia, we tested the REH to bridge this gap in the literature by employing the autoregressive distributed lag (ARDL) cointegration approach. The main objective of our study is to conduct an empirical test of the REH in the Ethiopian context, using time series data, extending from 1990 to 2011.

\section{Literature review}

This section includes theoretical literature on the preconditions for the existence of the REH, and the theoretical framework of this study. It comprehensively discusses relevant empirical literature, which includes works that support the existence of the REH, those that do not, and others that provide inconclusive (mixed) results.

\subsection{Theoretical requirements for the existence of the REH}

The first requirement for the existence of the REH is the infinite horizon of individuals. The individuals' time horizon should be at least the same as that of the government. This is because if an individual's lifespan is limited and shorter than that of the government, borrowing will increase the net wealth of the individual if that person dies. Here, individuals are linked with future generations by altruistic gifts. Since individuals care about their children's well-being, they do not decide on a tax cut by increasing their consumption. Instead, they will buy securities and other fixed assets and transfer these assets to their families (Marinheiro [2001]).

The existence of a perfect capital market (liquidity unconstraint) is an essential element in maintaining the REH. According to Hayashi [1987], if consumers face quantity constraints (due to a high interest rate) on their borrowing, they also

HungaRian STATISTICAL REVIEW, VOLUME 3, NUMBER 2, PP. 26-49. DOI: 10.35618/hsr2020.02.en026 
face liquidity constraints. Therefore, they are unable to smooth out their consumption over an entire lifetime, they will lack an opportunity to select the tax burden, and they will become indifferent to the issue.

The other prerequisite for the existence of the REH is the presence of lumpsum taxes. Lump-sum taxation requires that a tax now be precisely equivalent to a tax the following year, and by assumption raises the same present value of revenue. Debt and taxes must be equivalent. Moreover, failure to allow fully for the future by virtue either of finite horizons or of fiscal targets is inconsistent with the lump-sum assumption. Any lump-sum tax must be inter-temporally neutral, both in the sense that it does not distort between the present and future consumption when used in all periods at a constant rate, and in the sense that a tax differential between periods does not induce any taxpayer response (Brennan-Buchanan [1980]). However, in reality, taxes are not lump sum. Instead, tax liability is substantial if future income is high, and it is low if the income is small. Hence, with household lifetime resources becoming uncertain, this may lead to an increase in current consumption (Romer [1996], Marinheiro, [2001]). According to Romer [1996], if individuals do not optimise their consumption fully over the long term, the Ricardian equivalence will not hold. Furthermore, the perfect foresight assumption is one of the basic assumptions for the occurrence of the REH, even though it is difficult to achieve in an uncertain world (De Grauwe [1996], Marinheiro [2001]).

Even though the assumption of lump-sum taxes does not seem like a real-life phenomenon, some studies have considered it as a factor that affects the consumption pattern of households and individuals. For example, Geerolf-Grjebine [2019] considered it by raising the arguments of a supply-side economist's perspective, in which lump-sum tax is the most efficient factor in distorting people's consumption behaviour. Similarly, Sandmo [1985] argues that lump-sum taxes have pure income effects on consumption, and used the lump-sum tax as a benchmark in his discussion about the efficiency of alternative tax systems with respect to savings decisions. More specifically, in a study regarding the theory of taxation for developing countries, the World Bank [1988] confirmed that lump-sum taxes have income effects that affect consumption of taxed goods and welfare. Concurrently, government budget decisions are often made on lump-sum basis; parliaments decide on spending first, on deficit second, and the ministry of finance should find the resources (taxes) to finance the expenditures. In this process, taxes are de facto lump-sum taxes.

\subsection{The theoretical framework}

The two main methods of testing the REH are through the consumption function and interest rate approaches. The consumption function approach tries to assess

HungaRian STATISTICAL REVIEW, VOLUME 3, NUMBER 2, PP. 26-49. DOI: 10.35618/hsr2020.02.en026 
whether increases in government debt are considered net wealth by individuals and create increases in private consumption. However, the interest rate approach evaluates whether deficits lead to an increase in interest rates (Marinheiro [2001], Aderemi [2014]). Discriminating between the Ricardian equivalence and the perfect capital markets hypothesis for an open economy is the main problem of the interest rate approach. In an open economy, even when the consumers are not Ricardian, the interest rate may remain unchanged even though their consumption increases in response to a budget deficit, and when it is assumed that the interest rates across countries are equalised by international capital flows. Given the domestic interest rate, a budget deficit may be financed through an inflow of capital. However, in this case, it would create a deficit in the current account, which leads to the socalled twin-deficit phenomenon, when the Ricardian equivalence does not hold (Marinheiro [2001]).

Furthermore, the consumption function approach can be examined by reduced-form (structural) consumption functions and the Euler equation. The Kormendi [1983], Modigliani-Sterling [1986], Bernheim [1987], PerelmanPestieau [1993], Cardia [1997], and Leachman [1996] methods are the most popular from the reduced-form (structural) consumption function categories. Among these methods, this study follows the Bernheim model [1987] to test the existence of the $\mathrm{REH}$ in the case of Ethiopia. The reason for using a structural consumption approach relative to the Euler equation approach is that the latter needs several restrictions in order to obtain an observable consumption function, such as the imposition of a constant real rate of return, and the specification of a specific form of utility function, similar to the quadratic utility function, in order to aggregate the Euler equation across individuals (Adji [2007]). Additionally, the Euler approach requires the incorporation of a rational expectation optimisation framework (Aschauer [1985], Gupta [1992]). However, the structural consumption function is less restrictive compared with the Euler approach (Kormendi [1983], Bernheim [1987]). We chose the Bernheim model [1987] among other types of reduced-form (structural) consumption functions for various reasons (for more detail, see Section 2).

According to Bernheim [1987], several authors set out to estimate an equation such as the following:

$$
C_{t}=\alpha_{0}+\alpha_{1}\left(Y_{t}-T_{t}\right)+\alpha_{2}\left(T_{t}-G_{t}-r_{t} D_{t}\right)+\alpha_{3} G_{t}+\alpha_{4} D_{t}+\alpha_{5} W_{t}+\alpha_{6} \mathbf{X}_{t}+\varepsilon_{t}
$$

Here, $\alpha_{0}$ is an intercept term, all $\alpha_{1}-\alpha_{6}$ are long-run coefficients, and $\varepsilon_{t}$ is the error term. Besides, $C$ is consumption, $Y$ is national income, $T$ is tax revenues, $G$ is government spending, $D$ is debt, $W$ is private wealth, $r$ is the interest rate, and $\mathbf{X}$ is a vector of other exogenous variables (so that $Y-T$ is disposable income

Hungarian StatisticAl ReVIEW, VOlume 3, NumBER 2, PP. 26-49. DOI: 10.35618/hsr2020.02.en026 
and $T-G-r D$ is government surplus). Furthermore, Bernheim [1987] identified the second group of authors' estimate as:

$$
C_{t}=\beta_{0}+\beta_{1} Y_{t}+\beta_{2}\left(T_{t}-G_{t}-r_{t} D_{t}\right)+\beta_{3} G_{t}+\beta_{4} D_{t}+\beta_{5} W_{t}+\beta_{6} \mathbf{X}_{t}+\eta_{t}
$$

where $\beta_{0}$ is an intercept term, all $\beta_{1}-\beta_{6}$ are long-run coefficients, and $\eta_{t}$ is a stochastic error term.

Bernheim [1987] agreed that equations /1/ and /2/ are almost similar; specifically, if the interest rate is time-invariant, then one obtains $/ 2 /$ from $/ 1 /$ through a linear transformation of variables. This implies that his initial function (equation /1/), which was used as a base for equation $/ 2 /$, was non-linear.

Finally, the REH concept is criticized on the necessity of aggregation, as behaviour is on individual level but testing is executed at macro level.

According to Stoker [2010], the econometrics of aggregation is about modelling the relationship between individual (micro) behaviour and aggregate (macro) statistics, so that data from both levels can be used for estimation and inference about economic parameters. Hence, econometrics of aggregation refers to creating a framework where information on individual behaviour together with co-movements of aggregates can be used to estimate a consistent econometric model.

Several scholars have discussed the individual-aggregate connection; for example, Stoker [2010] who reviewed the way household consumption is aggregated, based on Gorman's [1953] and Theil's [1954] works. Initially, Stoker [2010] set some assumptions such as the quantity purchased $\left(q_{i t}\right)$ of a given product by households in a large population over a given time period $t$ is determined by household income $m_{i t}$, as in the following formula:

$$
q_{i t}=\alpha_{i}+\beta_{i} m_{i t}
$$

where $\alpha_{i}$ represents base level consumption and $\beta_{i}$ represents household $i$ 's marginal propensity to spend on the product. For aggregation, we shall also consider what type of link there is between average quantity and average income:

$$
\bar{q}_{t}=\frac{1}{n_{t}} \sum_{i=1}^{n_{t}} q_{i t} \text { and } \bar{m}_{t}=\frac{1}{n_{t}} \sum_{i=1}^{n_{t}} m_{i t}
$$

where households are listed as $i=1, \ldots, n_{t}$. Nevertheless, what happens if the household income is changed by a new policy? How does average quantity purchased $(\Delta \bar{q})$ change in response to the change in average income $(\Delta \bar{m})$ ?

Hungarian StaTISTICAL REVIEW, Volume 3, NuMBER 2, PP. 26-49. DOI: 10.35618/hsr2020.02.en026 
With a transfer policy, any group of households could be targeted for the new income. A full schedule of how much new income goes to each household as well as how they spend it seems like a complex list of details to follow, especially if the population is large. However, in this case, there are two main approaches to aggregation - exact aggregation and distributional restrictions (for more details, see Blundell-Stoker [2005], Stoker [2010]).

\subsection{Empirical literature}

This section presents the empirical studies that consider the REH. Here, we cluster the studies based on their findings: those that supported the $\mathrm{REH}$, those that did not support the REH, and those that arrived at mixed (inconclusive) results in the course of research.

The earliest study regarding testing of the REH was that of Tanner [1979], using Yawitz-Meyer and the life cycle models in the case of the US for the period from 1947 to 1974. The study found that the REH existed for the US during the study period. Similar findings were obtained by Kormendi [1983] employing the ordinary least squares (OLS) estimation technique in the case of the US for the years between 1930 and 1976. Further, Evans [1988] - applying the generalised method of moments estimation technique and using quarterly data from Q2 1947 to Q4 1985 supported the REH for the US. Similarly, Kormendi-Meguire [1990], employing the Engle and Granger approach, confirmed the existence of the REH in the case of the US for the period from 1931 to 1985.

When we consider studies of other countries, Leiderman-Razin [1988] applied the non-linear least squares approach (from the Thrift Savings Plan program) and used monthly data from September 1980 to December 1985. The study supported the REH in the case of Israel. Further, Evans [1993] confirmed the existence of the REH for nineteen Organisation for Economic Co-operation and Development countries using Hansen's [1982] approach for the period between 1960 and 1988. Moreover, Issler-Lima [2000], following the Johansen cointegration approach in the case of Brazil, supported the presence of the REH during the study period from 1947 to 1992. Furthermore, using three different (OLS, fixed effect, and random effect) estimation techniques for ten developing economies in the period from 1976 to 1998, Giorgioni-Holden [2003] found the presence of the REH. Similar findings were obtained by Olasunkanmi-Akanni [2013] for the case of Nigeria following the Johansen cointegration approach and the error correction mechanism for the years between 1981 and 2011. Finally, using a new methodology (ARDL) and two sample periods (from 1980 to 2014 and from 1988 to 2014), MosikariEita [2017] confirmed the existence of the REH in the case of Lesotho.

HungaRian STATISTICAL REVIEW, VOLUME 3, NuMBER 2, PP. 26-49. DOI: 10.35618/hsr2020.02.en026 
Unlike the above empirical studies, there are different findings that did not support the REH. For example, in the case of the US, Buiter-Tobin [1979] confirmed that the REH did not hold by following the Kochin regression approach and using yearly data from 1949 to 1976. By employing the OLS method, Kazmi [1994] found that the REH did not exist for the period from 1960 to 1988 in the case of Pakistan. Similar results were also obtained for Pakistan by Waqas-Awan [2011] (for the period between 1973 and 2009) and Saeed-Khan [2012] (for the period between 1972 and 2008) using the Johansen cointegration approach. Likewise, applying quarterly data from Q1 1981 to Q3 1996 and employing the vector error correction model (VECM) in the case of Greece, Drakos' findings [2001] did not support the REH. Vamvoukas-Gargalas [2008] obtained the same result as Drakos [2001] for the case of Greece using cointegration analysis, Granger causality tests, and the impulse response approach for the period from 1948 to 2001.

From the theoretical framework of this study, we understood that the consumption function approach (such as structural consumption functions and the Euler equation) is viable in testing the REH. Hence, Marinheiro [2001] used both the structural and Euler consumption function approaches. Additionally, he used the Kormendi [1983] consumption function, along with the error correction method (ECM). Ultimately, he found that the REH did not hold in the case of Portugal for the period from 1954 to 1997.

Employing the Granger causality test and VECM, Onafowora-Owoye [2006] confirmed that the REH did not exist in the case of Nigeria for the years between 1970 and 2001. Similar results were found in the case of Nigeria by Onyeiwu [2012] applying the OLS method and the ECM, and using quarterly time series data from 1994 to 2008. Likewise, employing the VECM and using quarterly time series data from Q1 1970 to Q4 2010, Odianye-Ebi [2013] concluded that the REH did not hold in Nigeria. Equivalently, Aderemi [2014] also observed that the REH did not exist for Nigeria, using the OLS method with annual time series data from 1981 to 2012. Employing the structural vector auto-regression estimation technique and monthly data from January 1992 to June 2009, Fang-Ma-Sheng [2010] found that the REH did not hold for China. Applying the ARDL cointegration approach, PicksonOfori-Abebrese [2018] did not support the REH for Sub-Saharan countries (Botswana, Ghana, Gambia, Nigeria, and Kenya) for the years from 1981 to 2014.

Finally, some studies presented inconclusive results. For example, KaaduUuskula [2004], using the instrumental variable technique, the full information maximum likelihood method, and quarterly data for the period between Q1 1997 and Q4 2002, obtained an inconclusive result for Estonia. Similarly, Gupta [1992] analysed the case of developing countries based on annual data between 1963 and 1986. The study found inconclusive results (it supported the REH only for the case of South Korea, Singapore, Pakistan, and Thailand).

HungaRian STATISTICAL REVIEW, VOLUME 3, NUMBER 2, PP. 26-49. DOI: 10.35618/hsr2020.02.en026 
From the empirical literature described above, some of the studies supported the REH, while others did not. There are also a few studies with inconclusive results. This is because of differences in the variables included in the model, the methodology, the time scope, and the case studies. Generally, the REH did not exist in the case of developing countries but its main requirements are fulfilled in most developed nations.

\section{Methodology}

This study uses secondary time series data from 1990 to 2011. The sources of data were WDI (World Development Indicator), IMF (International Monetary Fund), and countryeconomy.com. (See Appendix 1.) Furthermore, in the study we use only econometrics to test the REH in the case of Ethiopia.

\subsection{Data type, source, data analysis, and model specification}

This study uses the reduced-form (structural) consumption functions. In addition, it follows Bernheim's [1987] approach to test the existence of the REH in the case of Ethiopia. As we explained in Sub-section 1.2., Bernheim's [1987] original model (equation $/ 2 /$ ) is a linear transformation of equation $/ 1 /$, and therefore, we can understand that the base of Bernheim's [1987] model is non-linear. Furthermore, all variables in our model are measured in millions of USD, and the scatter plots show non-linearity among the variables. (See Appendix 2.) Hence, this study uses the natural logarithm to measure the elasticity and consider the non-linearity of variables in the model. Therefore, we can use the natural logarithm of Bernheim's [1987] original model as:

$$
\begin{aligned}
\ln C O N_{t} & =\beta_{0}+\beta_{1} \ln G D P_{t}+\beta_{2} \ln D E F_{t}+\beta_{3} \ln G O V C E_{t}+\beta_{4} \ln G O V D_{t}+ \\
& +\beta_{5} \ln W_{t}+\beta_{t} \mathbf{X}+\eta_{t}
\end{aligned}
$$

where $C O N$ is private consumption, $G D P$ is the gross domestic product, $D E F$ is a budget deficit, GOVCE is government consumption, GOVD is government debt, $W$ is wealth, $\mathbf{X}$ represents a vector of variables capturing the socio-economic conditions of the countries, and ln stands for natural logarithm. However, various problems are encountered while estimating equation $/ 2$ / for the case of Ethiopia, such as

HungaRian STATISTICAL REVIEW, VOLUME 3, NUMBER 2, PP. 26-49. DOI: 10.35618/hsr2020.02.en026 
the unavailability of data on wealth. To solve these problems, Bernheim [1987] suggested dropping the wealth variable because of its unavailability. Furthermore, Bernheim [1987] used growth in GDP and growth of population as the socioeconomic factors. However, for our case, adding these variables leads to the regression result 'singular matrix', and therefore, they were dropped. Finally, we have modified the original Bernheim model as follows:

$$
\ln C O N_{t}=\beta_{0}+\beta_{1} \ln G D P_{t}+\beta_{2} \ln D E F_{t}+\beta_{3} \ln G O V C E_{t}+\beta_{4} \ln G O V D_{t}+\eta_{t} . / 6 /
$$

The REH holds ${ }^{1}$ when $\beta_{2}=\beta_{3}=\beta_{4}=0$. If government consumption substitutes private consumption, then $\beta_{3}<0$, while if it complements it, then $\beta_{3}>0$. Note that Ethiopia has a negative budget balance in the study period, and this study uses the terminology of budget deficit by changing the budget balance into positive.

\subsection{ARDL model specification}

To empirically analyse the long-run relationships and dynamic interactions among the variables of interest, the model has been estimated by using bounds testing (or ARDL) cointegration procedure, which was initially presented by PesaranShin [1999] and further extended by Pesaran-Shin-Smith [2001]. The procedure is adopted because of its several advantages over the conventional type of cointegration techniques. First, relative to other multivariate cointegration techniques, such as that of Johansen and Juselius, the bounds test procedure is simple since it allows the cointegration relationship to be estimated by the OLS once the lag order of the model is known. Second, the bounds testing procedure does not require the order of integrations of all the variables included in the model to be the same, similar to other techniques, such as the Johansen approach. It is appropriate irrespective of whether the regressors in the model are purely $\mathrm{I}(0)$, purely $\mathrm{I}(1)$, or mutually integrated (Fosu-Magnus [2006], Bakry-Almohamad [2018]). The results of the augmented Dicky-Fuller (ADF) unit root test, shown in Table 1, indicate that the time series variables under examination are integrated of different orders (mixed). Hence, the choice of the ARDL cointegration approach enables us to test the long-run relationships among these variables. Third, the ARDL cointegration approach is a statistically significant approach and more valid than other cointegration techniques for a small sample size (Fosu-Magnus [2006], Bakry-Almohamad [2018]). This study uses yearly time series data from 1990 to 2011 , which is considered a small sample

${ }^{1}$ GDP is part of the consumption function, thereby the REH does not state any constraint about $\beta_{1}$.

Hungarian Statistical ReVIEW, VOlume 3, NumBer 2, PP. 26-49. DOI: 10.35618/hsr2020.02.en026 
(Narayan-Smith-Nandha [2004]). The procedure will, however, fail in the presence of I(2) series (Fosu-Magnus [2006]). Fourth, unlike the Johansen and Juselius residual-based cointegration tests, this method is efficient and cannot lead to contradictory results, especially when there are more than two I(1) variables under consideration (Beyene-Kotosz [2020]). When we see our variable, four out of five variables are I(1), and the ARDL cointegration approach thus eliminates contradictory findings. Fifth, this technique (ARDL) includes information on the structural break in time series data and does not suffer from low predicting power. In Ethiopia, there were three structural breaks from 1990 to 2011 (in 1992, 1993, and 2003). Therefore, the choice of the ARDL cointegration approach enables us to consider structural breaks in our study. The sixth advantage of this approach is that the model takes a sufficient number of lags to capture the data-generating process in a general to specific modelling framework (Muhammad [2009]). Seventh, it estimates the short- and long-run components of the model simultaneously, removing the problems associated with omitted variables and autocorrelation. Eighth, this technique generally provides unbiased estimates of the long-run model and valid $t$-statistics even when some of the regressors are endogenous (Srinivasan-Kumar-Ganesh [2012]). Having the above advantages and following Bernheim's [1987] approach as a framework, the general ARDL model that we use in this study is:

$$
\begin{aligned}
\Delta \ln C O N_{t} & =\alpha_{0}+\sum_{i=1}^{p} \beta \Delta \ln C O N_{t-i}+\sum_{i=0}^{p} \delta \Delta \ln G D P_{t-i}+\sum_{i=0}^{p} \gamma \Delta \ln D E F_{t-i}+ \\
& +\sum_{i=0}^{p} \varphi \Delta \ln G O V C E_{t-i}+\sum_{i=0}^{p} \sigma \Delta \ln G O V D_{t-i}+b_{0} \ln C O N_{t-1}+ \\
& +b_{1} \ln G D P_{t-1}+b_{2} \ln D E F_{t-1}+b_{3} \ln G O V C E_{t-1}+b_{4} \ln G O V D_{t-1}+\eta_{t}
\end{aligned}
$$

where $b_{1}, b_{2}, b_{3}$, and $b_{4}$ are long-run multipliers, $\alpha_{0}$ is drift (constant term), and the coefficients of lagged values of the variables' difference $(\beta, \delta, \gamma, \varphi, \sigma)$ show the short-run dynamic structure. Furthermore, $\Delta$ is the first difference operator, and $p$ is the optimal lag length.

\subsection{ARDL cointegration procedures}

Testing for the stationarity status of all variables to determine their order of integration is the initial step in the ARDL cointegration approach, since unit root tests could be undertaken following the general formula of the ADF test. Accordingly, to verify the stationarity of variables, $\mathrm{ADF}$ is undertaken:

Hungarian Statistical ReVIEW, Volume 3, NuMBER 2, PP. 26-49. DOI: 10.35618/hsr2020.02.en026 


$$
\Delta y_{t}=\delta+\beta t+\alpha y_{t-1}+\sum_{t+2}^{n} \gamma_{i} \Delta y_{t-i}+\eta_{t}
$$

The hypothesis to be is $H_{0}: \alpha=0, H_{1}: \alpha<0$.

Reject $H_{0}$ if $t_{\alpha}=0$ is less than critical values.

Here, $y_{t}$ represents variables subject to the ADF test of stationary condition, in which all variables of the model are tested following the above formula of the unit root test. Here, all variables should be either integrated at order 0 , 1 , or mixed. To avoid spurious results, it is necessary to confirm that none of the variables is integrated of order 2 or beyond (Fosu-Magnus [2006]). Following the unit root test, the second step of the ARDL cointegration approach is the selection of the maximum lag length for general and optimal lag length for the long- and short-run equations, using different information criteria before we estimate the model. The most common information criteria for the selection of lag length are the Akaike information criterion (AIC) and the Schwarz Bayesian information criterion (SBIC). However, Pesaran-Shin [1999] and Narayan [2004] suggested choosing 2 as the maximum order of lags if the observations are annual. Once the maximum lag length is determined, the third step is an estimation of the general equation $/ 7 /$ and then testing the existence of a long-run relationship among the variables by conducting an $f$-test for the joint significance of the coefficients of the lagged levels of the variables. This means the null hypothesis $\left(H_{0}\right)$ for no cointegration among variables in equation /9/ against the alternative hypothesis $\left(H_{1}\right)$ is:

$$
H_{0}: b_{0}=b_{1}=b_{2}=b_{3}=b_{4}=0, \quad H_{1}: b_{0} \neq b_{1} \neq b_{2} \neq b_{3} \neq b_{4} \neq 0 \text {. }
$$

The $f$-test has a non-standard distribution that depends on: 1 . whether variables included in the model are $\mathrm{I}(0)$ or $\mathrm{I}(1) ; 2$. the number of regressors; and 3 . whether the model contains an intercept and/or a trend. The test involves asymptotic critical value bounds, depending on whether the variables are $\mathrm{I}(0), \mathrm{I}(1)$, or a mixture of both. Two sets of critical values are generated, one set of which refers to I(1) series, and the other to $\mathrm{I}(0)$ series. Critical values for $\mathrm{I}(1)$ series are referred to as the upper bound critical values, whilst the critical values for $I(0)$ series are referred to as the lower bound critical values. If the $f$-test statistics exceed their respective upper critical values, we can conclude that there is evidence of the long-run relationship between the variables, regardless of the order of integration of the variables. If the test statistics are below the upper critical value, we cannot reject the null hypothesis of no cointegration (Duasa [2007]). The fourth step is an estimation of the long- and short-run relationships, simultaneously. Once cointegration is established, the conditional ARDL long-run model is:

HungaRian StaTISTICAL REVIEW, VOLUME 3, NUMBER 2, PP. 26-49. DOI: 10.35618/hsr2020.02.en026 


$$
\begin{aligned}
\ln C O N_{t} & =\beta_{0}+\sum_{i=1}^{p} \beta \ln C O N_{t-i}+\sum_{i=0}^{q} \beta_{1} \ln G D P_{t-i}+\sum_{i=0}^{r} \beta_{2} \ln D E F_{t-i}+ \\
& +\sum_{i=0}^{s} \beta_{3} \ln G O V C E_{t-i}+\sum_{i=0}^{t} \beta_{4} \ln G O V D_{t-i}+\eta_{t} .
\end{aligned}
$$

This involves selecting the orders of the $\operatorname{ARDL}(p, q, r, s, t)$ for the model using AIC or SBIC. The ARDL specification of the short-run dynamics is derived by constructing an error correction model in the following form:

$$
\begin{aligned}
\Delta \ln C O N_{t} & =\mu_{0}+\sum_{i=1}^{p} \mu \Delta \ln C O N_{t-i}+\sum_{i=0}^{q} \mu_{1} \Delta \ln G D P_{t-i}+\sum_{i=0}^{r} \mu_{2} \Delta \ln D E F_{t-i}+ \\
& +\sum_{i=0}^{s} \mu_{3} \Delta \ln G O V C E_{t-i}+\sum_{i=0}^{t} \mu_{4} \Delta \ln G O V D_{t-i}+\lambda e c m_{t-1}+\eta_{t}
\end{aligned}
$$

where all coefficients of the short-run equation are coefficients relating to the shortrun dynamics of the model convergence to equilibrium, $\lambda$ is the speed of adjustment parameter, and $\mathrm{ecm}_{t-1}$ is the one period lagged error correction term. Finally, it is necessary to run diagnostic tests such as a serial correlation test using the Breusch-Godfrey serial correlation Lagrange multiplier (LM) test, a heteroscedasticity test using the Breusch-Pagan-Godfrey test, a normality test using the JarqueBera test, and stability tests using the cumulative sum (CUSUM) and CUSUM of squares (CUSUMSQ) tests

\section{Results and discussions}

This section contains the empirical results and their interpretations along with theoretical and empirical support. More specifically, the unit root test using the ADF with intercept and trend, the cointegration test, long- and short-run dynamics, and diagnostic (normality, heteroscedasticity, autocorrelation, and stability) tests of the model are presented. 


\subsection{Unit root and cointegration tests}

The result of the ADF shows that all variables except government consumption expenditure (it is I(0)) included in the model are I(1) at the $1 \%$ level of significance. (See Table 1.) Hence, having this mixed order of integration, we can proceed with the ARDL cointegration technique.

Table 1

\begin{tabular}{|c|c|c|c|}
\hline \multirow{2}{*}{ Variable } & \multicolumn{2}{|c|}{$\begin{array}{c}\mathrm{ADF} \text { test statistics } \\
\text { (with intercept and trend) }\end{array}$} & \multirow{2}{*}{$\begin{array}{l}\text { Order of } \\
\text { integration }\end{array}$} \\
\hline & Level & First difference & \\
\hline $\ln C O N$ & -0.966 & $-5.371 * * *$ & $\mathrm{I}(1)$ \\
\hline $\ln G D P$ & -2.262 & $-5.200 * * *$ & $\mathrm{I}(1)$ \\
\hline $\ln D E F$ & -3.134 & $-5.595 * * *$ & $\mathrm{I}(1)$ \\
\hline $\ln G O V C E$ & $-4.901 * * *$ & -2.649 & $\mathrm{I}(0)$ \\
\hline $\ln G O V D$ & -0.973 & $-4.653 * * *$ & $\mathrm{I}(1)$ \\
\hline
\end{tabular}

$* * * p<0.01$

Note. All the values in the table are $t$-statistics.

Table 2

\begin{tabular}{c|c|c}
\multicolumn{3}{|c}{ Cointegration test } \\
\hline $\begin{array}{c}\text { Significance } \\
\text { level (\%) }\end{array}$ & \multicolumn{2}{|c}{ Bound critical value } \\
\cline { 2 - 3 } & $\mathrm{I}(0)$ & $\mathrm{I}(1)$ \\
\hline 10.0 & 2.45 & 3.52 \\
\hline 5.0 & 2.86 & 4.01 \\
\hline 2.5 & 3.25 & 4.49 \\
\hline 1.0 & 3.75 & 5.06 \\
\hline
\end{tabular}

Note. F-statistics were used for testing the existence of cointegration. Value of the REH model: 8.06 ; number of independent variables: 4 .

We check the existence of cointegration among the variables by comparing the calculated $f$-statistics with the upper bound critical values at the $1 \%$ critical level of significance. Our result implies that the null hypothesis of no cointegration is rejected at the $1 \%$ level. As a result, there is a cointegration relationship between the variables in the model. (See Table 2.)

Hungarian StatisticAL ReVIEW, VOluME 3, NuMBER 2, PP. 26-49. DOI: 10.35618/hsr2020.02.en026 


\section{The long-run and short-run estimations}

In the model, the explanatory variables included together explain around 99\% of the systematic variation in consumption during the period being studied. The $f$-statistics are highly significant at the $1 \%$ level. Since the range of the Durbin-Watson (D-W) statistic is between 0 and 4 (where 2 means no autocorrelation), the D-W result (1.71) of our model shows the absence of serial correlation of the residuals in the system. However, the long-run equilibrium coefficients and their asymptotic standard error, the $t$-values, and the $p$-values are presented in Table 3 .

Table 3

Estimated long-run coefficients (ARDL [1, 0, 2, 0, 0] selected based on AIC)

\begin{tabular}{l|c|c|c}
\hline \multicolumn{1}{|c|}{ Variable } & Coefficient & Standard error & $t$-statistics (probability) \\
\hline $\ln G D P$ & 1.346 & 0.106 & $12.68(0.000)^{* * *}$ \\
\hline $\ln D E F$ & -0.025 & 0.054 & $-0.475(0.643)$ \\
\hline $\ln G O V C E$ & 0.016 & 0.085 & $0.194(0.848)$ \\
\hline $\ln G O V D$ & -0.102 & 0.055 & $-1.829(0.092)^{*}$ \\
\hline Constant & -4.480 & 1.486 & $-3.013(0.010)^{* *}$ \\
\hline$R^{2}$ & \multicolumn{3}{|c}{0.994} \\
\hline$f$-statistic & \multicolumn{3}{|c}{1.717 .08} \\
\hline D-W statistics & \multicolumn{3}{|c}{0.0000} \\
\hline Probability $(f$-statistic $)$ & &
\end{tabular}

$* p<0.1, * * p<0.05, * * * p<0.01$.

Note. The dependent variable is $\ln C O N$.

As we discussed earlier, the REH holds when $\beta_{2}=\beta_{3}=\beta_{4}=0$. Hence, the results show that only government debt affects private consumption negatively and significantly. The coefficient of government debt is -0.1 , which indicates that while other things were constant, a $1 \%$ increment was responsible for a $0.1 \%$ reduction in private consumption during the period being studied. Since $\beta_{4} \neq 0$, our result does not support the REH in Ethiopia. According to our data, government debt has a negative and significant effect on private consumption; this is consistent with the Keynesian crowding-out effect. Generally, these findings are largely in line with conventional Keynesian economics; hence, we can conclude that Ethiopia is a nonRicardian economy.

The result of the error correction model is presented in Table 4. In the short run, private consumption expenditure is positively and significantly affected by the level

Hungarian StatisticAl ReVIEW, VOluME 3, NumBER 2, PP. 26-49. DOI: 10.35618/hsr2020.02.en026 
difference of GDP. However, it is negatively and significantly affected by the level difference of government debt and lag difference of deficit. In the short run, a rise in the level difference of GDP by $1 \%$ results in a rise in the private consumption level in Ethiopia by $1.53 \%$. However, a $1 \%$ increment in the level difference of government debt and lag difference of deficit reduces the private consumption by 0.11 and $0.05 \%$, respectively. In both the long and short run, $\beta_{2}=\beta_{3}=\beta_{4}=0$ did not exist. Hence, Ethiopia is a non-Ricardian economy in both the short and long run.

The error correction term indicates the speed of adjustment in restoring equilibrium in the dynamic model. The ECM coefficient shows how slowly variables converge to equilibrium, and theoretically, it should have a statistically significant coefficient with a negative sign. This condition occurs in our model. In addition to this, the highly significant error correction term confirms the existence of a stable longrun relationship between variables. The coefficient of ECM $(-1)=-1.139$, implying that about $113 \%$ of the deviation of the actual private consumption from its equilibrium value is eliminated every year; hence, in this study, full adjustment to reach equilibrium would require less than a year.

Table 4

Error correction representation (ARDL [1, 0, 2, 0, 0] selected based on AIC)

\begin{tabular}{l|c|c|c}
\hline \multicolumn{1}{c|}{ Variables } & Coefficients & Standard error & $t$-statistics (probability) \\
\hline$D(\ln G D P)$ & 1.535 & 0.239 & $6.413(0.000)^{* * *}$ \\
\hline$D(\ln D E F)$ & -0.055 & 0.039 & $-1.407(0.184)$ \\
\hline$D(\ln D E F(-1))$ & -0.052 & 0.027 & $-1.876(0.085)^{*}$ \\
\hline$D(\ln G O V C E)$ & 0.018 & 0.097 & $0.194(0.849)$ \\
\hline$D(\ln G O V D)$ & -0.116 & 0.064 & $-1.814(0.094)^{*}$ \\
\hline$C o i n t E q(-1)$ & -1.139 & 0.164 & $-6.909(0.000)^{* * *}$ \\
\hline
\end{tabular}

$* p<0.1, * * * p<0.01$.

Note. The dependent variable is $D(\ln C O N)$.

Finally, the diagnostic tests of the model, such as the Jarque-Bera normality test, the Breusch-Godfrey serial-correlation LM test, the Breusch-Pagan-Godfrey heteroscedasticity test, the CUSUM, and the CUSUMSQ test, have been conducted. Hence, the estimated residuals did not provide any significant evidence of nonnormality, serial correlation, non-stability, or heteroscedasticity effect in the error term. (See Appendix 3.) 


\section{Conclusion}

The primary objective of this study was to test the existence of the REH empirically in the case of Ethiopia using annual time series data from 1990 to 2011 by employing the ARDL cointegration approach. We examined whether a long-run equilibrium relationship exists between private consumption and deficit, government expenditure, and government debt. The results provide substantial evidence against the prevalence of the REH in Ethiopia and support Keynesian debt non-neutrality. This is because the REH holds when no budget deficit, government consumption expenditure, and government debt affect the level of private consumption. Even though our result passed the first two requirements (deficit and government consumption expenditure), it did not fulfil the third requirement (government debt). Theoretically, the REH would be valid if there was the same discount rate for both public and private sectors, a perfect capital market, no liquidity constraint, consumers were rational, and there was certainty in the future incomes and taxes, as well as a non-distortionary tax. However, not all the above assumptions were found in the case of Ethiopia. It is an expected result for a developing country. Finally, this study has its limitations, even though it tried to fill the literature gap. We dropped certain variables due to unavailability of data (wealth) and singularity of the regressed variable, because of the short time series data relative to the variables included in the model. Hence, future research could extend similar investigations by considering these factors.

\section{Appendices}

\section{Appendix 1}

\begin{tabular}{l|l|c}
\multicolumn{3}{c}{ Definitions, measurement, and data sources } \\
\hline \multicolumn{1}{c|}{ Variable } & \multicolumn{1}{|c}{ Definition and measurement } & Source \\
\hline $\ln C O N$ & Natural logarithm of private consumption expenditure (USD) & WDI \\
\hline $\ln G D P$ & Natural logarithm of GDP (USD) & WDI \\
\hline $\ln D E F$ & Natural logarithm of government fiscal deficit (USD) & countryeconomy.com \\
\hline $\ln G O V C E$ & $\begin{array}{l}\text { Natural logarithm of general government final consumption } \\
\text { expenditure (USD) }\end{array}$ & WDI \\
\hline $\ln G O V D$ & Natural logarithm of government debt (USD) & IMF \\
\hline
\end{tabular}




\section{Appendix 2}

The following figure is sketched to confirm that the relationship between the variables is non-linear. To show this, we used the raw data of the variables before they were transformed to natural logarithm.

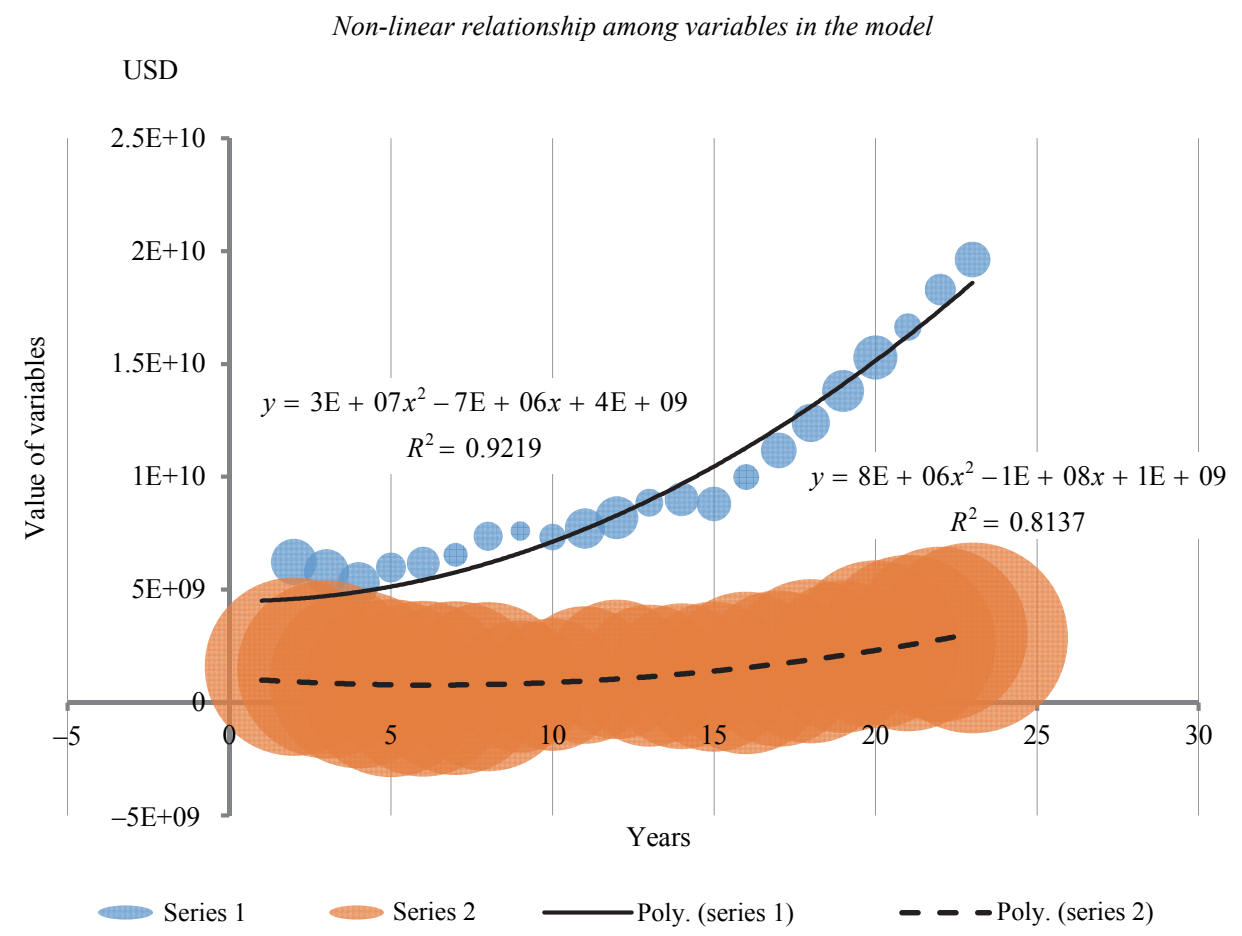

Note. Series 1 describes private consumption, GDP, and the deficit in USD all together, while series 2 represents private consumption, government consumption expenditure, and government debt. In addition, Poly. (series 1) and Poly. (series 2) refer to polynomial equations for series 1 and series 2, respectively. To confirm the existence of non-linear relationships in our model, we tested different equations (linear, quadratic, and polynomial). It was found that the optimal equation, in which the $R^{2}$ is the highest, is Poly. (series 1).

HUNGARIAN STATISTICAL REVIEW, VOLUME 3, NUMBER 2, PP. 26-49. DOI: 10.35618/hsr2020.02.en026 


\section{Appendix 3}

a) Normality test

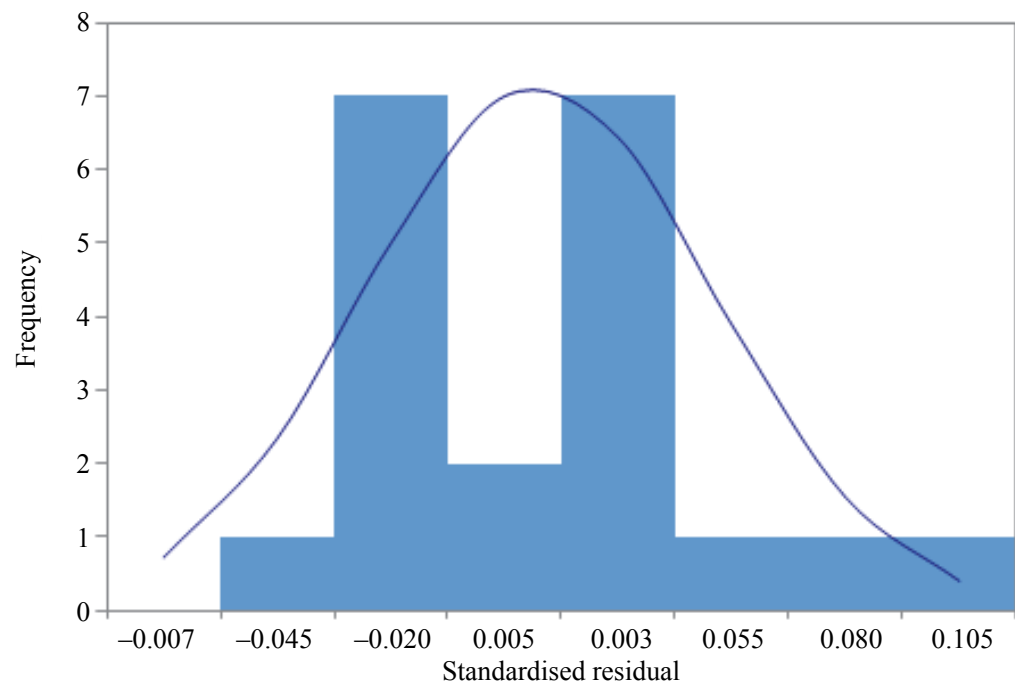

Descriptive statistics (normality test) of residuals

\begin{tabular}{l|c}
\hline Mean & $-2.00187 \mathrm{E}-15$ \\
\hline Standard error & 0.008612917 \\
\hline Median & 0.003974461 \\
\hline Standard deviation & 0.038518135 \\
\hline Sample variance & 0.001483647 \\
\hline Kurtosis & 0.216917201 \\
\hline Skewness & 0.528767331 \\
\hline Range & 0.152887111 \\
\hline Minimum & -0.068531635 \\
\hline Maximum & 0.084355476 \\
\hline Sum & $-4.00374 \mathrm{E}-14$ \\
\hline Count & 20 \\
\hline Confidence level (95.0\%) & 0.018027042 \\
\hline Jarque-Bera test & 0.833849002 \\
\hline Probability & 0.659071 \\
\hline
\end{tabular}

Note. The table shows that the probability value is greater than $0.05(5 \%)$ thus we can accept the null hypothesis, that is, the residuals are normally distributed.

HungaRian STATISTICAL REVIEW, VOLUME 3, NuMBER 2, PP. 26-49. DOI: 10.35618/hsr2020.02.en026 


\section{b) Autocorrelation test}

\begin{tabular}{l} 
Breusch-Godfrey serial correlation LM test \\
\hline \begin{tabular}{l|l}
$f$-statistic & 0.522 \\
\hline Prob. $f(2,10)$ & 0.609 \\
\hline${\text { Obs* } R^{2}}^{2}{ }^{2}(2)$ & 1.891 \\
\hline Prob. chi & 0.389 \\
\hline
\end{tabular}
\end{tabular}

c) Test of heteroskedasticity

Breusch-Pagan-Godfrey heteroskedasticity test
\begin{tabular}{l|c}
\hline$f$-statistic & 1.933 \\
\hline Prob. $f(7,12)$ & 0.151 \\
\hline Obs* $R^{2}$ & 10.601 \\
\hline Prob. $\operatorname{chi}^{2}(7)$ & 0.157 \\
\hline Scaled explained SS & 3.589 \\
\hline Prob. chi ${ }^{2}(7)$ & 0.826 \\
\hline
\end{tabular}

Note. SS: scaled score.

d) Stability test

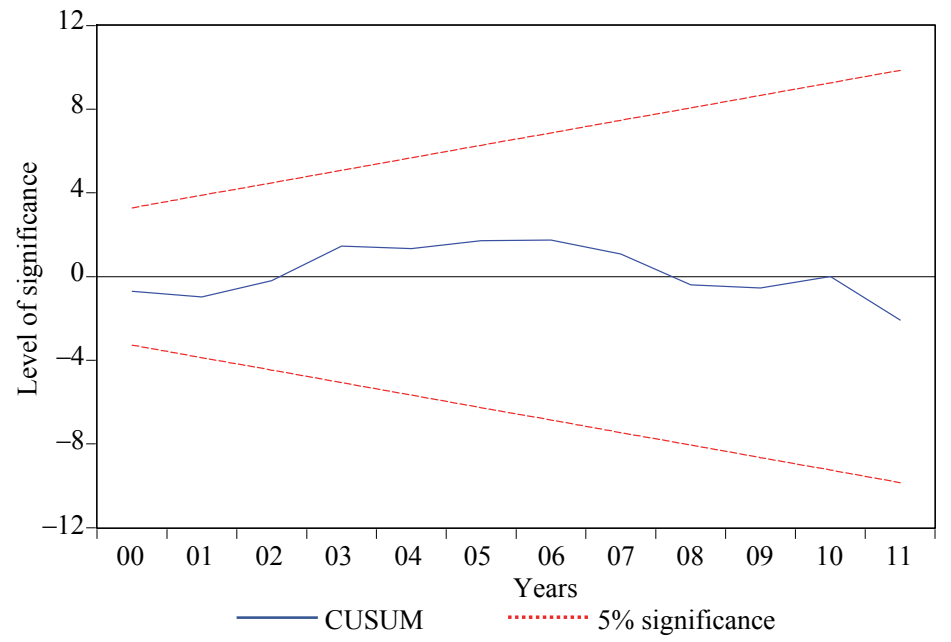

HUNGARIAN STATISTICAL REVIEW, VOLUME 3, NUMBER 2, PP. 26-49. DOI: 10.35618/hsr2020.02.en026 


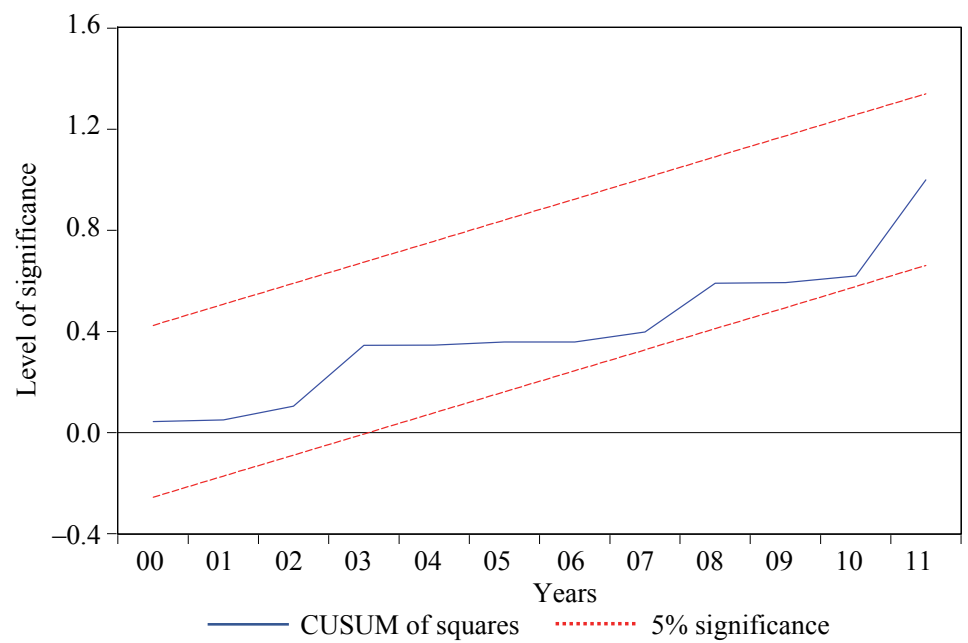

Note. The CUSUM test is based on the cumulative sum of recursive residuals. This option plots the cumulative sum together with the $5 \%$ critical lines. However, the CUSUM of squares test provides a plot of the cumulative sum against the pair of $5 \%$ critical lines. Both tests find parameter instability if the cumulative sum goes outside the area between the two critical lines. Hence, the stability test of this study shows that the blue line lies within the $5 \%$ boundaries, which implies that our model is stable.

\section{References}

AdEREMI, T. [2014]: An empirical application of debt neutrality to the Nigerian economy: Further evidence. International Journal of Economic Practices and Theories. Vol. 4. No. 4. pp. 493-503.

ADJI, A. [2007]: Essays on Ricardian Equivalence. PhD Dissertation. Department of Economics Georgia State University. Atlanta.

Aschauer, D. [1985]: Fiscal policy and aggregate demand. American Economic Review. Vol. 75. Issue 1. pp. 117-127.

Bakry, W. - Almohamad, S. [2018]: Further evidence on Middle East and North Africa financial markets integration. International Journal of Economics and Business Research. Vol. 15. No. 1. pp. 1-22. https://doi.org/10.1504/IJEBR.2018.10008873

BERNHEIM, B. D. [1987]: Ricardian equivalence: An evaluation of theory and evidence with three comments. In: Fisher, S. (ed.): NBER Macroeconomics Annual. National Bureau of Economic Research. Cambridge. pp. 263-315. https://doi.org/10.1086/ma.2.4623723

BRENNAN, G. - Buchanan, J. M. [1980]: The logic of the Ricardian equivalence theorem. Finanz Archiv/Public Finance Analysis. New Series. Bd. 38. H. 1. pp. 4-16.

Beyene, S. D. - Kotosz, B. [2020]: Macroeconomic determinants of external indebtedness of Ethiopia: ARDL approach to co-integration. Society and Economy. Vol. 42. Issue 3. pp. 313-332. https://doi.org/10.1257/0022051054661486

Hungarian STATISTICAL REVIEW, VOLUME 3, NuMBER 2, PP. 26-49. DOI: 10.35618/hsr2020.02.en026 
Blundell, R. - StokeR, T. M. [2005]: Heterogeneity and aggregation. Journal of Economic Literature. Vol. 43. No. 2. pp. 347-391.

Buiter, W. - ToBIn, J. [1979]: Debt neutrality: A brief review of doctrine and evidence. In: von Furstenberg, G. (ed.): Social Security versus Private Saving. Ballinger. Cambridge. pp. 39-63.

CARDIA, E. [1997]: Replicating Ricardian equivalence tests with simulated series. The American Economic Review. Vol. 87. No. 1. pp. 65-79.

DALYOP, G. T. [2010]: Fiscal deficits and the growth of domestic output in Nigeria. JOS Journal of Economics. Vol. 4. No. 1. pp. 153-173.

De Grauwe, P. [1996]: International Money. $2^{\text {nd }}$ Edition. Oxford University Press. Oxford.

DRAKOS, K. [2001]: Testing the Ricardian equivalence theorem: Time series evidence from Greece. Journal of Economic Development. Vol. 26. No. 1. pp. 149-160.

DuAsA, J. [2007]: Determinants of trade balance: A case of Malaysia. Journal of Economic Cooperation. Vol. 28. No. 3. pp. 21-40.

Evans, P. [1988]: Are consumers Ricardian? Evidence for the United States. Journal of Political Economy. Vol. 96. No. 5. pp. 983-1004. https://doi.org/10.1086/261572

Evans, P. [1993]: Consumers are not Ricardian: Evidence from nineteen countries. Economic Inquiry. Vol. XXXI. Issue 4. pp. 534-548. https://doi.org/10.1111/j.14657295.1993.tb00889.x

FANG, W. - MA, J. - SHENG, Y. [2010]: An empirical test on the validity of China's fiscal policy based on the Ricardian equivalence proposition. International Journal of Business and Management. Vol. 5. No. 8. pp. 209-214. https://doi.org/10.5539/ijbm.v5n8p209

Fosu, O. - Magnus, F. [2006]: An examination of foreign direct investment, trade and growth relationships: A case of Ghana. American Journal of Applied Science. Vol. 3. No. 11. pp. 2079-2085. https://doi.org/10.3844/ajassp.2006.2079.2085

GeErolf, F. - GrJebine, T. [2019]: The Macroeconomic Effects of Lump-sum Taxes. https://pdfs.semanticscholar.org/8532/aad7922c36f6d0607552d3f032c584d38359.pdf?_ga= 2.88201691.1731124738.1581074953-1573886360.1580830290

Giorgioni, G. - Holden, K. [2003]: Does the Ricardian equivalence hold in developing countries? International Review of Applied Economics. Vol. 17. No. 2. pp. 209-221. https://doi.org/10.1080/0269217032000064062

Gorman, W. M. [1953]: Community preference fields. Econometrica: Journal of the Econometric Society. Vol. 21. No. 1. pp. 63-80. https://doi.org/10.2307/1906943

Graham, F. - Himarios, D. [1996]: Consumption, wealth, and finite horizons: Tests of Ricardian equivalence. Economic Inquiry. Vol. XXXIV. No. 3. pp. 527-544. https://doi.org/10.1111/j.1465-7295.1996.tb01395.x

GuPTA, K. [1992]: Ricardian equivalence and crowding out in Asia. Applied Economics. Vol. 24. Issue 1. pp. 19-25. https://doi.org/10.1080/00036849200000099

HANSEN, L. P. [1982]: Large sample properties of generalized method of moments estimator. Econometrica. Vol. 50. No. 4. pp. 1029-1054. https://doi.org/10.2307/1912775

HAYASHI, F. [1987]: Tests for liquidity constraints: A critical survey and some new observations. In: Bewley, T. F. (ed.): Advances in Econometrics: Fifth World Congress. Vol. 2. Cambridge University Press. Cambridge.

Hungarian StatisticAl ReVIEW, Volume 3, NuMBER 2, PP. 26-49. DOI: 10.35618/hsr2020.02.en026 
HeIJDRA, B. J. [2002]: The Foundation of Modern Macroeconomics. Oxford University Press. New York.

IsSLER, J. V. - LiMA, L. R. [2000]: Public debt sustainability and endogenous seigniorage in Brazil. Journal of Development Economics. Vol. 62. No. 1. pp. 131-147. https://doi.org/10.1016/S0304-3878(00)00078-X

KaAdu, H. - Uuskula, L. [2004]: Liquidity Constraints and Ricardian Equivalence in Estonia. Working Papers of Eesti Bank. No. 7. https://core.ac.uk/download/pdf/7033114.pdf

KAZMI, A. [1994]: Private consumption, government spending, debt neutrality: Resolving Kormendi-Feldstein-Modigliani controversy. The Pakistan Development Review. Vol. 33. No. 4. pp. 1055-1071. https://doi.org/10.30541/v33i4IIpp.1055-1071

Kim, S. - Roubini, N. [2008]: Twin deficit or twin divergence? Fiscal policy, current account, and real exchange rate in the U.S. Journal of International Economics. Vol. 74. No. 2. pp. 362-383. https://doi.org/10.1016/j.jinteco.2007.05.012

KoRMENDI, R. [1983]: Government debt, government spending, and private sector behavior. American Economic Review. Vol. LXXIII. No. 5. pp. 994-1010.

Kormendi, R. - Meguire, P. [1990]: Government debt, government spending, and private sector behavior: Reply and update. American Economic Review. Vol. 80. No. 3. pp. 604-617.

LEACHMAN, L. L. [1996]: New evidence on the Ricardian equivalence theorem: A multicointegration approach. Applied Economics. Vol. 28. No. 6. pp. 695-704. https://doi.org/10.1080/000368496328443

LEIDERMAN, L. L. - RAZIN, A. [1988]: Testing Ricardian neutrality with an intertemporal stochastic model. Journal of Money, Credit and Banking. Vol. 20. No. 1. pp. 1-21. https://doi.org/10.2307/1992664

Marinheiro, C. F. [2001]: Ricardian Equivalence: An Empirical Application to the Portuguese Economy. Discussions Paper Series. No. 01.12. University of Coimbra and Katholieke Universiteit Leuven. Leuven.

Modigliani, F. - Sterling, A. G. [1986]: Government debt, government spending and private sector behaviour: A further comment. The American Economic Review. Vol. 80. No. 3. pp. 600-603.

MosiKARI, T. J. - EITA, J. H. [2017]: Empirical test of the Ricardian equivalence in the Kingdom of Lesotho. Cogent Economics \& Finance. Vol. 5. No. 1. pp. 1-11. https://doi.org/10.1080/23322039.2017.1351674

MuHAmmad, S. [2009]: Nominal and real devaluations relations: A case of Pakistan. International Journal of Applied Econometrics and Quantitative Studies Cooperation. Vol. 9. No. 1. pp. 85-108.

NARAYAn, P. K. [2004]: Fiji's tourism demand. The ARDL approach to cointegration. Tourism Economics. Vol. 10. No. 2. pp. 193-206. https://doi.org/10.5367/000000004323142425

NARAYAN, P. - SMith, R. - NANDHA, M. [2004]: Interdependence and dynamic linkages between the emerging stock markets of South Asia. Accounting and Finance. Vol. 44. No. 3. pp. 419-439. https://doi.org/10.1111/j.1467-629x.2004.00113.x

ODIANYE, J. C. - EBI, U. K. [2013]: The relationship between budget deficit and interest rate: Evidence from Nigeria. European Journal of Business and Social Sciences. Vol. 2. No. 1. pp. 158-167.

OKPANACHI, U. M. - ABIMIKU, C. A. [2007]: Fiscal deficit and macroeconomic performance: Survey of theory and empirical evidence. In: Ogiji, P. (ed.): The Nigerian Economy: Challenge and Directors for Growth in the Next 25 Years. Aboki Publisher. Makurdi.

Hungarian STATISTICAL REVIEW, VOLUME 3, NuMBER 2, PP. 26-49. DOI: 10.35618/hsr2020.02.en026 
OlasunKanMi, O. I. - AKAnNI, O. P. [2013]: Testing the validity of Ricardian equivalence in Nigeria. International Centre of Science Education and Academic Research for Scholars. Vol. 1. No. 1. pp. 164-174.

OnAfowora, A. O. - OwoYe, O. [2006]: An empirical investigation of budget deficit and trade deficit: The case of Nigeria. Journal of Developing Areas. Vol. 39. No. 2. pp. 153-174. https://doi.org/10.1353/jda.2006.0009

ONYEIwU, C. [2012]: Domestic debt and the growth of Nigerian economy. Research Journal of Finance and Accounting. Vol. 3. No. 5. pp. 45-56.

Perelman, S. - Pestieau, P. [1993]: The determinants of the Ricardian equivalence in the OCDE countries. In: Verbon, H. A. A. - van Winden, F. A. A. M. (eds.): The Political Economy of Pubic Debt. North Holland. Amsterdam. pp. 181-195.

PeSARAN, M. H. - ShIN, Y. [1999]: An autoregressive distributed lag modeling approach to cointegration analysis. In: Strom, S. (ed.): Econometrics and Economic Theory in the $20^{\text {th }}$ Century: The Ragnar Frish Centennial Symposium. Cambridge University Press. Cambridge. pp. 371-413. https://doi.org/10.1017/CCOL521633230.011

Pesaran, M. H. - Shin, Y. - SMith, R. J. [2001]: Bound testing approaches to the analysis of level relationships. Journal of Applied Econometrics. Vol. 16. No. 3. pp. 289-326. https://doi.org/10.1002/jae.616

Pickson, R. B. - Ofori-AbeBreSE, G. [2018]: Ricardian equivalence hypothesis in the Sub-Sahara African countries. Journal of Economic Integration. Vol. 33. No. 3. pp. 466-487.

ROMER, D. [1996]: Advanced Macroeconomics. McGraw Hill. New York. https://doi.org/10.11130/jei.2018.33.3.466

SAeEd, S. - Khan, A. M. [2012]: Ricardian Equivalence Hypothesis and Budgetary Deficits: The Case of Pakistan. International Islamic University. Islamabad.

SAndmo, A. [1985]: The effects of taxation on savings and risk taking. In: Auerbach, A. J. Feldstei, M. (eds.): Handbook of Public Economics. Vol. I. North Holland. Amsterdam. pp. 265-311. https://doi.org/10.1016/S1573-4420(85)80008-2

SRinivasan, P. - Kumar, S. - GANeSh, L. [2012]: Tourism and economic growth: A case of Sri Lanka. The Romania Economic Journal. Vol. XV. No. 45. pp. 211-225.

Stoker, T. M. [2010]: Aggregation (econometrics). In: Durlauf, S. N. - Blume, L. E. (eds.): Macroeconometrics and Time Series Analysis. Palgrave Macmillan. London. pp. 1-14. https://doi.org/10.1057/9780230280830_1

TANNER, J. [1979]: An empirical investigation of the tax discounting - A comment. Journal of Money, Credit and Banking. Vol. 11. No. 2. pp. 214-218. https://doi.org/10.2307/1991834

THEIL, H. [1954]: Linear Aggregation of Economic Relations. North-Holland. Amsterdam.

Vamvoukas, A. G. - Gargalas, N. V. [2008]: Testing Keynesian proposition and Ricardian equivalence: More evidence on the debate. Journal of Business and Economics Research. Vol. 6. No. 5. pp. 67-76. https://doi.org/10.19030/jber.v6i5.2419

WAQAS, M. - AWAN, M. S. [2011]: Are Pakistan consumers Ricardian? Economics and Business Review. Vol. 13. No. 3. pp. 161-177.

WoRLD BANK [1988]: The Theory of Taxation for Developing Countries. World Bank Research Publication. Oxford University Press. Washington, D.C.

YAwitZ, J. - MEYeR, L. [1976]: An empirical test of the extent of tax discounting. Journal of Money, Credit and Banking. Vol. 8. No. 2. pp. 247-254. https://doi.org/10.2307/1991745

Hungarian StatisticAl ReVIEW, Volume 3, NuMBER 2, PP. 26-49. DOI: 10.35618/hsr2020.02.en026 